\title{
The difficulty of bridging between art education and design education for children: A reception of Marion Richardson in Japan after WW2
}

\author{
Mariko Kaname / Atomi University / Tokyo / Japan \\ Shigeru Maeda / Kyoto Seika University / Kyoto / Japan
}

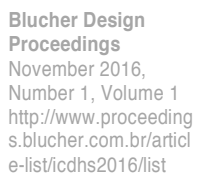

\begin{abstract}
Since the defeat in WW2, the Japanese education system has undergone significant reform under the influence of the American army of occupation GHQ. Particularly, the new education philosophy derived from John Dewey's theory initiated this reform. The provisional plan for curriculum guidelines established in 1947 according to this trend has set a new subject of arts and handicrafts, which focused a practical design education, rather than a creative art expression. Meanwhile, Japanese educators introduced western drawing education, conducted by educators including Marion Richardson in the early 20th century. As an example of the reaction to this, Japanese design educator Haru Madokoro recognized that Richardson's methodology showed what was considered as lack of arts and handicrafts in Japanese education from her perspective. This paper will clarify some issues of Japanese art/design education for children, investigating the introduction of English drawing education into Japan and its response after WW2.
\end{abstract}

\section{Keywords}

Pattern, form, drawing, art/design education for children, Japan, England

\section{Introduction}

Since the mid 18c, children have been considered inherently creative, so that arts and crafts classes in Japanese primary schools are also based on this notion. Actually, children are less creative than we think. Looking at the works of children in lower grades of primary school, it can be seen that children are easily able to reproduce stereotypical drawings from manga or TV anime, rather than to patiently seek their own expressions of their experiences. Art teachers often spent their time trying to dispel the influence of adults from infants in accordance with an opening remark of Jean-Jacques Rousseau's Emile (Rousseau, 1957, p.5). They manage to prevent their students from copying existing stereotypes, by giving hard-to-use materials such as torn colour paper or self-made pens instead of store-brought colour pencils. Childlike scribbles are often idealized in early primary school art classes.

When students go to the upper grades or junior high schools, teachers discouraged them from making such scribbles as though their time for development was over, and required them to make a poster on traffic safety or drawing letters with a serif typeface on section papers, introducing elements of design education. However, if it is accepted that a child is essentially creative, it must wondered as to why are they not left just as they are.

Design education connects with some issues of occupational training for children, teaching them how to make a livelihood, for example. Without the element of occupational training, art class must be disregarded by both teachers and students because it is not required as examination subjects for university. In 1951, Taizo Inamura, a painter as well as a professor of art education in Ibaraki University, remarked that child art education in Japan was freed from "German romantic and unpractical idea", and went toward "American practical science" (Inamura, 1951, p.137). He also predicted art education would be increasingly disregarded in this tendency.

Thus, there is less continuity in art education than our expectation between an art class for lower grades and that for upper grades in primary school, because these are based on different causes: how to develop a child's creativity or their imagination and how to make a livelihood. There is no coherent methodology that bridges the gap between child's scribbles and design. In 1958, Japanese design educator Haru Madokoro pointed that the Japanese education of arts and handicrafts lacked "the mind and methodology of composing and designing" (Madokoro, 1958, p.64). As an important clue to cover this failure, she introduced activities by English art educator 
Marion Richardson. However, her concern shifted from Richardson a few years later. In this paper, we will firstly highlight an advantage of Richardson's methodology of education in the above noted perspective. Secondly, we will examine why it did not enter the mainstream in Japan, considering the trend of art education in the country.

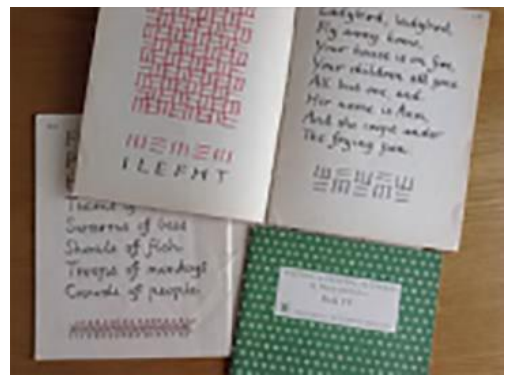

Fig. 1: Writing and Writing Patterns

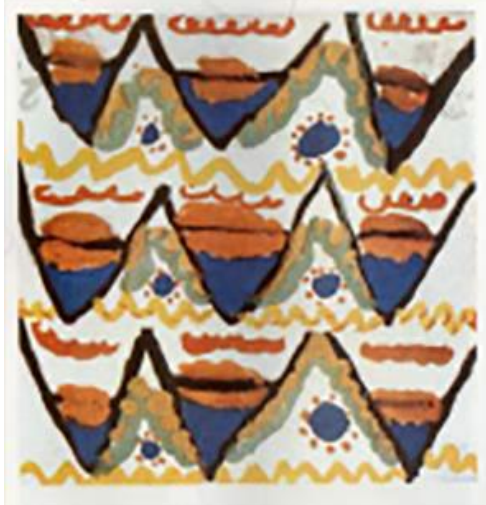

Fig. 2 \& 3: Works of Richardson's students

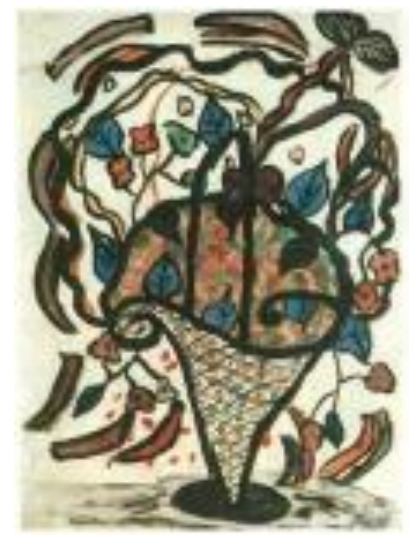

\section{Richardson's drawing education for children}

Roger Fry and Herbert Read, who had an enormous influence on art/design in the English-speaking world, both looked at Richardson's education. Fry is well-known as an art critic who introduced French post-impressionists in London in 1910. In 1910s, he managed the design workshop "Omega Workshops" and became a member of the Board of Trade and appointed a Committee on Art and Industry in 1931. Read had worked in the ceramics department at the Victoria and Albert Museum (1922-31), published his book Art and Industry in 1934, shortly after "Gorell Report (1932)" issued in the 1931 committee as mentioned above.

When Fry organized the exhibition of children's drawings at Omega Workshops, Richardson searched for a new post in London. After unsuccessful interviews, she visited him through his sister Margery's introduction at an exhibition venue in 1917 (Richardson, 1954, p.30-1). He had discovered the "primitive" as a common trait among Modern art and children's drawings (Fry, 1917, p.226). Richardson felt sympathy with his idea and showed her students' drawing to him. Fry added these drawings to the exhibition.

Read referred to Richardson's education in the above-mentioned book and maintained correspondence with her. There is, however, a difference between Read and Richardson according to their attitudes toward "pattern", which she emphasized in art education for children. Read had served as the president of the Society for Education in Art (SEA) for over 20 years (1946-1968), and on her death in 1948 he edited her memorial issue of Athene. Nonetheless, Read had misjudged that Richardson's methodology could be adapted for exclusively art education for younger children. Richardson disapproved of his comment and wrote to him on June 13th, 1935: "The babies of four make pictures as well as pattern, and even the most intelligent of the seniors continue to make patterns upto the school leaving age of seventeen or so" (Richardson, 1935).

When Richardson showed Fry her students' drawings, he understood her innovative methodology. Breaking with mainstream methodology of observation-based drawing of that time, she focused on children's own expression of their mental images. One reason for this emphasis was the influence of Shut-Eye Drawing and Visualisation classes given by Robert Catterson-Smith, a lecturer and designer associated with the Arts and Crafts Movement at the Birmingham College of Art and Design (MacDonald, 1970, p.327). Prior to this, as an example of an alternative to the South Kensington Approach, Thomas Ablett developed a drawing education and systematized its method at the Royal Drawing Society. Even though Ablett encouraged free drawings inspired by children's memories or imagination, his approach was inclined to moral conditioning and shifted towards the imitation of nature through observation-centered training in art (Richardson, 1925, pp.9-11). Eventually, Richardson did not adopt his method for her practices. She even raised doubts over John Ruskin's doctrine 'go to nature,' to which Ablett responded, "Are we, therefore, to conclude that art is natural?" (Richardson, 1947, p.3). In view of Drawing Syllabus of Dudley Girls' High School 1915 to 1916 , it includes pattern making as the sixth of seven items. Here she warns children not to depend on outside images. In the process of making patterns, "the girls are urged to wait until their mental picture is vivid before attempting to draw. They must in every case make a drawing with their eyes shut, before the ordinary work is begun" (Richardson, 1917-18). She also states that "we must be careful that in the name of visualising and free 
expression our teaching does not become rigid and uncreative again" (Richardson, 1919, p.2). The drawing education that Richardson aimed for did not leave children to scribble in the name of "free expression" and was different from the vocational training and academic art education. Richardson argued that the appropriate help of the teacher was necessary for students, as distinct from repressive instruction or sheer abandonment of instructors. The teacher should train the child to be faithful when recording the child's mental imagery (Richardson, 1947, p.4).

The idea of "pattern" is characteristic of Richardson's educational methodology in rejecting both the imitation of outside nature and letting inner nature of children free. As indicated earlier, for her "pattern" is inseparable from "picture" and children could make both patterns and pictures in parallel independently from their growing stage. Because pattern is a basic element for both art and design in her view (Richardson, 1934, p.1), there was no reason to distinguish between education for the lower grades and for the upper grades of primary school. Pattern is the center of her education for children. It can develop children's spontaneous "scribbles" into both "picture" and "design". In 1935 she published Writing and Writing Patterns as a guidebook for transforming scribbles into unified works. It aimed at not only being a drill for handwriting, but also of developing the child's sense of form [figs. 1, 2, 3]. She claimed that "by scribbling, they were teaching themselves both to write and to draw," and "in scribble the same patterns occurred over and over again," (Richardson, 1954, p.55). Thus the "pattern" has a formal coherence or unity beyond the categories of mere decorative elements.

\section{Fry's "concept-symbol" and richardson's "pattern"}

Richardson's educational methodology seems to be very similar to Roger Fry's theory of modern art, which refused the imitation of nature as well as absolute abstraction. Both theories laid stress on grasping forms based on individual experiences and its process of patternization. Fry's idea that we should not see subject or motifs, but look at the composition of formal elements such as colours and lines in a picture coincides with Richardson's "pattern". The pattern can be drawn even with one's eyes shut and even adapted to commercial design. This supports Madokoro's view that finding a clue to cover the lack of Japanese design education in Richardson's methodology emphasizing "pattern".

As we mentioned earlier, children tend to repeat existing stereotypes as an end goal. Japanese art educator Mitsuru Fujie calls this stereotype gainen-ga (concept picture) [fig. 4]. It is often just a copy of popular anime characters, so that children draw human figures with almost the same shape and expression. Meanwhile, Fujie distinguish a relation between forms transforming and being improved according to experience as zu-shiki (scheme) [fig. 5]. This idea reminds us of concept- symbol proposed by Roger Fry. He dismissed classical imitations of nature and modern impressionist realism as just a copy. He advocated post-impressionists finding the same attitude as some artists in early renaissance. They are equally "primitive" and their attitude is to be "intensely moved by events and objects, and primitive art is the direct expression of his [artist's] wonder and delight" (Fry, 1917, p. 267). Not only are outside motifs or inner emotions important, but also the relationship between both, which makes empirical components. Fry called this attitude of trying to visualize their experience immediately as "primitive" and the process of this visualisation as "concept-symbol" (Fry, 1910, p.334). If we can identify this Fry's concept-symbol with Fujie's "scheme", we may also consider it as an equivalent to Richardson's "pattern". In making pattern, children have to stop renewing their experience through looking at outside objects in order just to refine their copy and have to focus only on visualizing their experience with their eyes shut. For Fry and Richardson, a starting point of design was not abstract but based on individual experience which was an interaction between outside object and inner emotion.

While Fry thought that the "patterns" made by the child were not art, he believed they had the potential to be translated into beautiful textiles with minor modifications (Fry, 1996, p.409). This reminds us of his experiments with the Omega Workshops in the 1910s, where young artists adapted the formal patterns in their artworks into the design of everyday goods such as furniture and furnishing [figs. 6, 7].

Richardson also taught her students to translate some of their "patterns" into household

materials; potatos, carrots and rubber erasers, which were found in children's everyday life, were used to make prints. For example, linen curtains were printed by hand from lino cuts and hung in the staff room (Richardson, 1946, p.55) [fig. 8]. At a children's art and design exhibition in the Whitworth Gallery in Manchester in 1928, many people from the textile industry had an interest in some of her students' potato block-printed patterns (Richardson, 1946, p.55). 


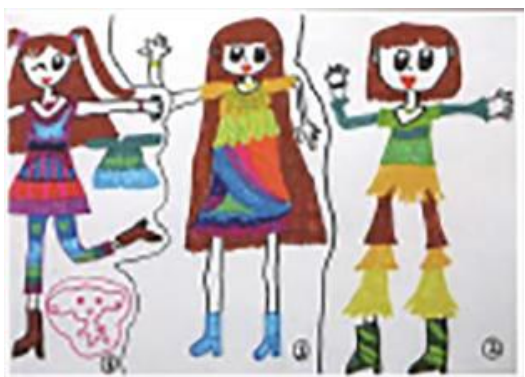

Fig. 4: Concept picture

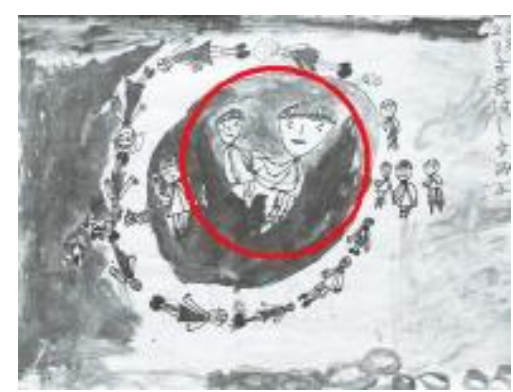

Fig. 5: Scheme

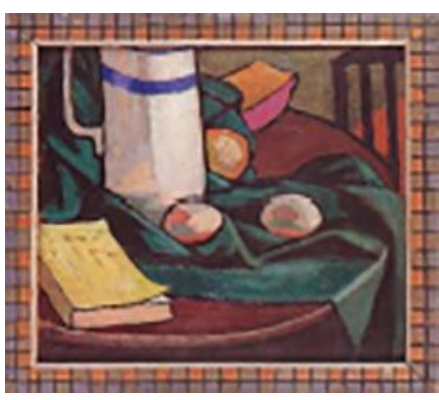

Fig. 6: Roger Fry, Amenophis oil on canvas

\section{How and why did richardson's educational methodology of design not go mainstream in japan?}

As we have seen, Richardson and Fry did not think that "pattern" was limited to child design education. However, even in Education through Art published in 1943, Read misunderstood her methodology as limited to basic design education for younger children. In his book, he put art education in center of general education in the manner of Friedrich Schiller and proposed stages of several art education according to types and development of children using personality psychology and style theory which was popular at that time. He shared the underlying view of identifying a mental development of children to the history of human race. A pioneer in the study of child art, English psychologist James Sully had already analysed children's drawings, comparing the drawings of "savages" or prehistoric men in his Study of Childhood (1895).

There is the same view among those who introduced Richardson's practices in Japan. Japanese design critic Shinji Koike, who introduced her memorial issue of Athene in a Japanese journal on art education, also understood a development of child's creativity by comparing it to the history of expressions of the primitive race (Koike, 1949, p.10-2). Both Koike and Read coincidently cited Richardson's words: "Art is not an effort of will but a gift of grace - to the child at least, the simplest and most natural thing in the world" (Richardson, 1938). However, they neglected a question from Richardson, "Are we, therefore, to conclude that... man is born with the innate power to produce and to understand art, and that he loses it by living in a world where values are false and materialistic?" (Richardson, 1947, pp.3-4)

The first book-length translation of Richardson in Japanese was of her Art and the Child (1946) and published in 1958 by Inamura. He was not only involved in art education, but also editing the textbook titled Arts and Crafts of Children [Jidō no Zuga-Kōsaku] in 1952. In the mid 1950s, Inamura went to participate in the 9th International Congress of Art Education in London and witnessed pattern-focused art education proposed by Richardson. On this particular year, Madokoro reviewed this translation and found in it "the mind and methodology of composing and designing" as above-mentioned. However, in 1958, school education system faced a great turning point in Japan. In this year, the old Teaching Guide for the Japanese Course of Study (draft proposal) of 1947 was revised without the letters "draft proposal" in its title and turned into more strong supervision. In new guideline, educational goals were set in every 2 grades of primary school according to the growing stages of children. Comparing 1947 version to that of 1951, the former had been regardful of the variety of child's development, the latter ordered to execute the school education absolutizing growth stages. This order is obviously incompatible with Richardson's view. In just a few short years, Inamura's focus moved from Richardson to Austrian art educator Viktor Lowenfeld who put emphasis on expressing child's inner experience freely, illustrating some traits of children's

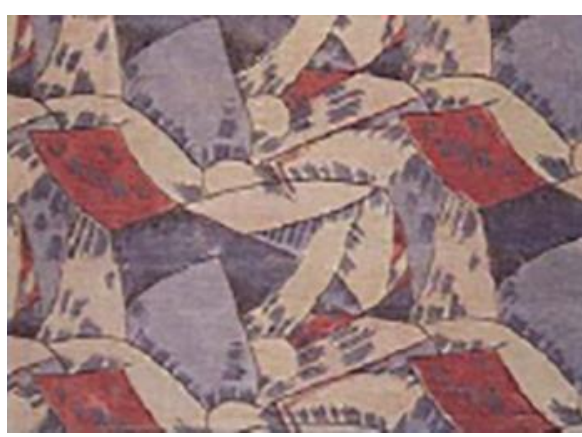

Fig. 7: Roger Fry's design expression in each stage of growth.

In 1980, the second version of the translation of Art and the Child was published after being out of print for long time. The translator's preface shows that the book, originally published as Richardson's autobiography and without any detailed presentation of her practice, is recognized as an opponent of utilitarian design education that GHQ pushed ahead in Japan, or as one of traditional romantic and expressionistic propositions of art education. It is probable that the second translation was accepted along with a similar reaction to the first version. For example, Japanese schoolteachers have commented about her practices as "sweet romanticism" or "feminine and over-sweetness". Until the end of the 20th 
century, we failed to find articles or books about Richardson in Japan. Japanese scholars seem unaware of her educational methodology, or her words: "The new ways sometimes only pretend to be free, pretend to encourage the child's own expression of his own vision" (Richardson, MR3049, p.2).

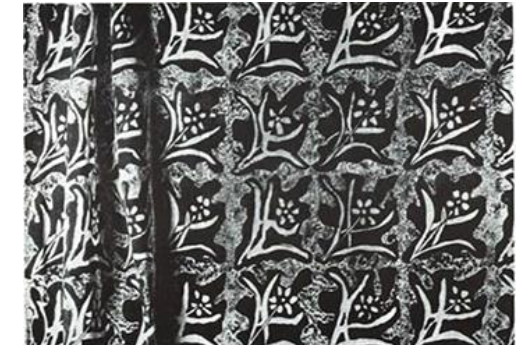

Fig. 8: Made Marian (a textile pattern)

\section{Conclusion}

Today in Japan, theory of design education for children often adopts a basic part of Bauhaus method such as Johaness Itten's colour theory, though it is not for children in itself. Several activities in Art Education Centre founded by Japanese art critic Masaru Katsumi in 1955 had a great impact on these tendencies. A similar movement appeared as Basic Design through the 1960s in England, but they still overlook the gap between primary art education and senior design education, as mentioned earlier. However basic it may seem, the Bauhaus method does not attract younger children, because it does not always stress children's own expression. Although several movements for children's art education emerged at a private level in 1950s Japan against a policy of government, Marion Richardson had been left out of the mainstream. But using her method, we could have bridged the gap between education for children and for adolescent. Even when they grow up, we can keep their interest in drawings or paintings, as far as they are encouraged to keep renewing their own "pattern" not to keep reproducing the "stereotypes" of childness.

\section{References}

Fry, R. (1910) 'The Art of the Bushmen' Burlington Magazine, no.16, March, p.334-8.

Fry, R. (1917) 'Children's Drawings' Burlington Magazine, p.226.

Fry, R. (1928) 'Henri-Matisse' A Roger Fry Reader, p.406-9.

Fukuda, T., Fukumoto, K. and Mogi, K. (2015) The Basic Art Education, 4th edition, Tokyo: Kenpakusha. Inamura, T. (1977) Arts and handicrafts education, Tokyo: Meisei Press.

Macdonald, S. (2004) The history and philosophy of art education, reprinted, Cambridge: Lutterworth Press. Madokoro, H. (1958) 'Reading Richardson's Art and the Child', Art in Education, vol.10, no.1, July, p.64. Marion Richardson's documents in the Birmingham City University Art and Design Archives Richardson, M. 'Drawing Syllabus 1915-1916', MR.

Read, H. (1934) Art and Industry, New York: Hartcourt, Brace and Company.

Read, H. (1945) Education through Art, 2nd edition, London: Faber and Faber.

Richardson, M. (1925) 'L.C.C. Lectures', MR3424B.

Richardson, M. (1925) MR3049.

Richardson, M. (1934) 'Teaching Design to Children', MR.

Richardson, M. (1935) 'Letter to Herbert Read', MR3373.

Richardson, M. (1938) 'Note by Miss Marion Richardson', the Catalogue of Exhibition of Children's Drawings at the County Hall, MR.

Richardson, M. (1947) 'Children's Drawings', Athene, vol. 4, no. 1, pp.3-4.

Richardson, M. (1954) Art and The Child, London: University of London Press (Japanese introduction with Katsumi, M. and translated by Inamura, T. (1958), Tokyo: Meisei Press); second translation by Kitajo, S and Kitajo, J (1980).

Richardson, M. (1972) Writing and Writing Patterns, 22nd impression, London: University of London Press. Rousseau, J. J. (1957). Emile. Trans. by Barbara Foxley. London: J. M. Dent \& Sons.

Shinji, K. (1949) 'Marion Richardson' School Art, vol.1, July, p.10-2.

\section{Biographical note}

Mariko Kaname is working as an Associate Professor at Atomi University, specializing Aesthetics. Dissertation: Roger Fry's Critical Theories: the logic of sensibility. Shigeru and I are currently engaging in the three years research project "Provincial Avant-garde Art Movement: Leeds Arts Club" supported by Japanese government.

Shigeru Maeda is a professor on Aesthetics and Film Studies at Kyoto Seika University. Dissertation: Gilles Deleuze and Aesthetics. 